\title{
Korpusavusteinen diskurssianalyysi japaninsuomalaisten kielipuheesta
}

\author{
LiISA-MARIA LEHTO
}

\section{Väitöksenalkajaisesitelmä Oulun yliopistossa 19. toukokuuta 2018}

Mitä kielelle käy, kun suomalainen muuttaa ulkomaille ja oleskelee siellä useita vuosia? Tämä oli ensimmäinen tutkimusaiheeseeni liittynyt kysymys, kun hyvä ystäväni oli asunut ulkomailla jo jonkin aikaa ja tapasin hänet hänen lomaillessaan Suomessa. Mietin, tuleeko kieleen aksentti, hukkuuko sanasto, hiipuvatko vivahteet ja merkitykset.

Samankaltaisia kysymyksiä voi huomata, kun vilkaisee vaikkapa sanomalehtien yleisönosastokirjoituksia tai virittää keskustelun suomen kielen tilanteesta. Näissä keskusteluissa pohditaan kielen muutosta ja säilymistä monella tasolla, mutta ei useinkaan puhuta ulkomailla asuvista suomalaisista tai siitä, mitä siirtolaisten kielelle tapahtuu. Usein mietitään, onko suomen kieli huonontumassa, koska se muuttuu, tai mitä tapahtuu, kun kieleen tulee vieraita vaikutteita vaikkapa englannista. Tällaiset puhumisen tavat elävät myös tutkimusaineistossani, vaikka tutkimuskysymykseni ja tutkimuksen konteksti ovat aivan toisia. Suomen kieli Suomessa kestää lainasanat, ja elävän kielen on tarkoituskin muuttua (Mantila 2010). Suomesta muuttaneet siirtolaiset taas voivat hukata sanoja hetkittäisesti, ja joillekin voi kehittyä vuosien saatossa aksentti. Uskaltaisin silti sanoa, että aikuisen Suomessa syntyneen nykysiirtolaisen kielelle ei käy juuri mitään (ensikielen attritiosta ks. esim. Köpke \& Schmid 2004) - varsinkaan siihen verrattuna, miten muutosalttiita ovat kielikäsitykset ja kieliin suhtautuminen. Vaikka kieli siis ei radikaalisti muutu, kielen merkitykset yksilölle muuttuvat. Kielten roolit elämässä vaikuttavat kielivalintoihin ja sitä kautta siihen, kuinka kielet nähdään ja koetaan. Nämä seikat näkyvät kielestä puhumisen tavoissa, kielidiskursseissa.

Väitöskirjassani Korpusavusteinen diskurssianalyysi japaninsuomalaisten kielipuheesta olen yhtäältä tutkinut rooleja, tehtäviä ja merkityksiä, joita Suomessa syntyneet ja Japaniin muuttaneet suomalaiset antavat eri kielille. Toisaalta olen tarkastellut metodin, korpusavusteisen diskurssianalyysin, toimivuutta. Selvitän, kuinka sen avulla voi löytää kielidiskursseja puhutusta suomenkielisestä aineistosta. Tutkimuksen aineistona on 
14 nauhoitettua haastattelua ja 7 parikeskustelua, joista suurimman osan olen kerännyt kenttätyömatkalla Japanissa vuonna 2014. Nauhoitteiden litteraateista olen muodostanut erikoiskorpuksen, josta olen etsinyt diskursseja WordSmith Tools -korpusohjelman (Scott 2008) avulla.

Olen tutkinut sitä, mitä haastattelemani japaninsuomalaiset sanovat kielistä. Diskurssianalyytikkona minua ei siis kiinnosta, millainen maailma todellisuudessa on, vaan se, miten maailmaa rakennetaan kielen avulla. Millaisen kuvan informantit muodostavat suomesta, japanista ja englannista - äidinkielestä, vieraan kulttuurin kielestä ja lingua francasta? Kielidiskurssit näkyvät esimerkiksi siinä, kuinka kieliä nimetään tai luonnehditaan. Onko kieli esimerkiksi kaunis tai vaikea? Entä millaisen roolin kieli saa - onko se väline, itselle rakas asia vai ainoastaan hyödyke? Suomen kieli nimetään äidinkieleksi, mutta se voidaan nähdä myös työkaluna, joka käy tarpeettomaksi japaninkielisessä ympäristössä. Japanin kielestä taas puhutaan esimerkiksi taitona ja englantia kuvataan lähinnä käyttöön tarkoitettuna yleiskaluna.

Diskurssit ovat toistuvia ja suhteellisen sitkeitä, ja niissä elää itsestäänselvyyksiä ja luonnollistumia, jotka analyysin avulla on tarkoitus tehdä näkyviksi (ks. esim. Pietikäinen \& Mäntynen 2009: 27, 73). Esimerkiksi diskurssi kielen hyvyydestä ja huonoudesta kertoo ajattelutavasta, jonka mukaan on olemassa vain yksi puhdas kielen muoto (kielellisestä purismista esim. Rintala 1998: 53). Diskurssien taustalla elävätkin kieliideologiat, sellaiset käsitykset ja uskomukset, jotka ovat yhteisön omaisuutta ja jotka tulevat konkreettisiksi puhumisen tavoissa (esim. Mäntynen, Halonen, Pietikäinen \& Solin 2012). Kielidiskurssit ovat siis yhtäl̈lä pysyväisluonteisia, ja ne uusiutuvat erilaisissa konteksteissa, erilaisten puhujien tuottamina (Boyd \& Palviainen 2015: 59). Toisaalta kieliin liitetyistä merkityksistä tulee siirtolaisuuden konteksteissa kelluvia, muuttuvia ja tilanteisiin sidottuja. Tällaisten puhetapojen ympärille työni ja analyysini kietoutuu.

Kielten rooli on muuttunut, kun liikkuvuus on lisääntynyt ja kommunikaatioteknologia parantunut (esim. Blommaert \& Rampton 2011: 3). Globalisaatio on toisin sanoen murtanut monenlaisia raja-aitoja. Kun ihmisestä on tullut liikkuvaisempi, kieletkään eivät ole enää aikaan ja paikkaan sidottuja (esim. mas. 2). Yksikielisessä ympäristössä kielen tai äidinkielen merkitystä itselle ei ole välttämättä edes tarpeen pohtia. Toisin voi käydä, kun siirtyy uuteen kieliympäristöön ja kun kielelliset tilanteet vaihtelevat. (Ks. esim. Grünthal 2009: 266, 284.) Näin on tutkimillani japaninsuomalaisilla. Haastateltavani ovat Suomessa syntyneitä suomalaisia, jotka ovat muuttaneet Japaniin eri aikoina ja eri syistä. Osa on asunut siellä jo vuosikymmeniä, toiset muutamia vuosia. Moni elää parisuhteessa japanilaisen tai muualta Aasiasta tulevan kanssa ja työskentelee japaninkielisessä ympäristössä. Englantia käytetään useimmiten ystävien kanssa tai joidenkin informanttieni tapauksessa myös työpaikalla.

Informanttini eivät ole tyypillinen ryhmä, johon siirtolaisuuden ja monikielisyyden tutkimus kohdistuu. Japaninsuomalaisia on noin 6oo, ja he eroavat vaikkapa amerikantai ruotsinsuomalaisista siirtolaisista monella tavalla. Näiden ryhmien motivaatiot ryhtyä siirtolaisiksi olivat ensinnäkin kotimaasta pois työntäviä syitä. Esimerkiksi heikko toimeentulo sai suomalaiset lähtemään paremman elintason perässä muualle. Japaninsuomalaiset ovat sen sijaan siirtolaisia, joita Japaniin ovat pikemminkin vetäneet erilaiset 
yksilölliset syyt, kuten avioliitto, opiskelu tai työ. Toiseksi japaninsuomalaiset eivät ole lähteneet Suomesta ryhminä vaan yksilöinä, eivätkä he myöskään muodosta Japanissa kovinkaan tiiviitä yhteisöjä. Suuri etäisyys kotimaahan, muuttaminen yksilönä ja suomalaisten muodostaman ryhmän puuttuminen vaikuttavat merkittävästi kielikäsityksiin ja -diskursseihin. Nykyisin erityisesti internet on parantanut yhteydenpitomahdollisuuksia. Mikään ei kuitenkaan muuta sitä tosiseikkaa, että suomenkielisestä ympäristöstä irtautuminen ja Japanin lähes täysin yksikielinen ympäristö tekevät informanttieni kontekstista erityisen.

Suomen kielen merkitys arkipäivässä muuttuu, kun muutetaan Japaniin. Suomen kieltä ei koeta arjessa kovin tärkeäksi, sillä sitä ei yksinkertaisesti voi käyttää. Japanin kontekstissa rapistuu myös englannin lingua franca -asema, joka on Euroopassa lähes itsestään selvä. Japanissa on melkein yhtä epätodennäköistä se, että englanti kelpaisi arkiseksi kommunikaatiovälineeksi, kuin se, että voisi hoitaa arkipäiväisiä kauppaasioita suomeksi. Kielitilanne on siis kokonaan toinen kuin Suomessa tai Euroopassa. Lisäksi japaninsuomalaiset ovat japanilaisessa yhteiskunnassa pieni, näkymätön ulkomaalaisjoukko, joka kuitenkin poikkeaa selvästi massasta. Paikallisista erottava ulkonäkö luo odotuksia kielen ja kielitaidon suhteen. Samanlaista tilannetta ei ole esimerkiksi ruotsinsuomalaisilla, joita ei ulkonäön perusteella erota paikallisista (Weckström 2011: 1, 103-104, 108, 150). Informanttini ovat sekä Japanin yhteiskunnan että suomalaissiirtolaisuuden kannalta ryhmä, joka jää helposti varjoon, kun huomio kohdistuu muunlaisiin siirtolaisuus- ja maahanmuuttokysymyksiin, vaikkapa pakolaisten tai työsiirtolaisten kielitilanteisiin (Vertovec 2007; Blommaert 2012). Japaninsuomalaisten kielelliset tilanteet ja kielidiskurssit ovat siitä huolimatta siirtolaisuuden moninaisuuden sekä yhteiskunnassa käytävän kielikeskustelun kokonaisuuden kannalta merkittäviä. Japaninsuomalaisten kaltaiset vapaasti liikkuvat suomalaiset omalta osaltaan muokkaavat käsitystä kielistä - erityisesti suomen kielestä. Käsittelen yksilöinä Suomesta lähteneitä ja toisista suomalaisista erillään eläviä henkilöitä, joten tutkimukseni tuottaa tietoa ryhmästä, jonka olemassaoloa ei edes ajatella. Kuten tiedämme, myös Suomessa erilaiset siirtolaisuuden ja monikielisyyden kysymykset ovat tätä päivää. Tarvitaankin tietoa siitä, kuinka erilaiset ihmisryhmät suhtautuvat kieliin, jotta voitaisiin reagoida muutoksiin yhteiskunnassamme.

Tarkastelen japaninsuomalaisten kielidiskursseja korpusavusteisesti: toinen tutkimuskysymykseni koskee sitä, millaisen kuvan kielidiskursseista korpusavusteinen menetelmä antaa. Diskurssianalyyttisissa tutkimuksissa aineiston käsittelyyn on käytetty erilaisia kvalitatiivisia ja kvantitatiivisia menetelmiä (ks. esim. Pietikäinen \& Mäntynen 2009). Käytän korpusavusteista menetelmää, jonka avulla saan diskurssit esiin ja joka osoittaa diskurssien olemassaolon kielen piirteissä. Hyödynnän analyysissani klustereita ja semanttista preferenssiä, joiden etsimiseen olen käyttänyt WordSmith Tools -korpusohjelmaa. Syötin ohjelmaan hakusanoiksi informanttieni arjessa käyttämät kielet eli suomen, japanin ja englannin, ja analyysi perustuu saatuihin hakutuloksiin. Klusterit ovat kiinteitä monisanaisia yksiköitä, jotka esiintyvät aineistossa toistuvasti toistensa kanssa (Kenny 2001). Olen tutkinut kolmisanaisia yksiköitä, jotka ovat frekventtejä aineistossani. Tällaisia ovat esimerkiksi <että suomen kieli> sekä <japani ja englanti $>$. Olen hakenut tällaisten klustereiden ympäristöistä erilaisia toistuvia puhumisen tapoja. 
Semanttinen preferenssi on suhde lemman tai sananmuodon ja niiden kollokaattien merkityssisältöjen välillä (Stubbs 2001: 65). Siinä hakusanan kanssa kollokoi ryhmä sanoja, joita yhdistää jokin semanttinen tekijä. Käyttämässäni tutkimuskirjallisuudessa semanttista preferenssiä havainnollistaa seuraava esimerkki: lekseemin lasillinen kanssa kollokoi sellaisia sanoja kuin maito, vesi ja samppanja. Nämä yhdessä muodostavat semanttisen luokan JUOMAT, joka on kaikkien edellä mainittujen sanojen yhteinen semanttinen nimittäjä. (Baker 2006: 86.) Työssäni olen luokitellut hakusanojen ympäristöistä tietyn määrän sanoja ja muodostanut niistä semanttisia luokkia. Aineistostani nousi esimerkiksi semanttinen luokka KOMMUNIKOINTI. Luokkaan kuuluu sellaisia sanoja kuin puhua, keskustella tai sähköposti. Semanttisten luokkien sisällöt puolestaan paljastavat diskursseja. Kattavaa semanttisen preferenssin tarkastelua tai klusterianalyysia ei ole kielidiskursiivisesta aineistosta aikaisemmin tehty. Käyttämäni menetelmä onkin Suomessa verrattain uusi, vaikkakin korpusavusteista diskurssianalyysia on viime vuosina alettu tehdä enenevässä määrin (ks. esim. Baker \& McEnery 2015; Jantunen 2018).

Lähtökohtanani oli ajatus, että eri kielistä puhuttaisiin hyvin eri tavalla. Sanoisin kuitenkin, että aineistoni havainnollistaa ennemmin yleisiä kielistä puhumisen tapoja kuin eroavaisuuksia eri kielten välillä. Tosin suomi erottuu sekä japanista että englannista, kun puhutaan kielten keskinäisistä työnjaoista. Suomea kuvataan itselle merkityksellisenä kielenä, kun taas japani ja englanti saavat välineellisen arvon. Kielidiskursseissa on yleismaailmallinen pohjavire, minkä vuoksi kielten keskinäiset erot eivät ole työni keskeisin tulos. En ole työssäni myöskään asettanut diskursseja suuruus- tai arvojärjestykseen. Syy tähän on se, että diskurssianalyysi on aina jäännöksellinen: jokin osa diskurssien kannalta merkittävästä aineksesta jää aina näkemättä. Siksi on hankala sanoa, mitkä diskurssit lopulta ovat määrältään suurempia tai merkittävämpiä. Useammin ja useassa paikassa toistuvat puhumisen tavat ovat ehkä tyypillisiä esimerkkejä sitkaista diskursseista. Kuitenkin poikkeavat ja harvinaisemmat diskurssit tulisi myös huomioida - ne ovat osa kuvaa, joka tutkittavasta ilmiöstä luodaan.

Olen analyysin eri vaiheissa havainnut, että informanttieni puhumisen tavoissa elää ikään kuin vastavoimia. Ne kuvaavat diskurssien dynaamisuutta ja niputtavat samalla diskursseja paremmin hallittaviksi kokonaisuuksiksi. Nämä vastavoimat ovat 1) tilanteisuus ja tärkeys, 2) muutos ja pysyvyys sekä 3) välineellisyys ja itseilmaisu. Vastaparien ensimmäiset jäsenet tilanteisuus, muutos ja välineellisyys kietoutuvat toisiinsa ja kuvaavat saman ilmiön eri puolia. Samoin tärkeys, pysyvyys ja itseilmaisu kuuluvat yhteen. Edellisiin voisi vielä lisätä ainakin osittain toisilleen vastakkaiset yhteisön ja yksilön näkökulmat, jotka elävät aineistossani ja vetävät puhumisen tapoja kahteen suuntaan. Tällä tarkoitan aineistossa esiintyviä ristiriitoja, joissa yksittäisen suomalaisen intressit asettuvat vastakkain japanilaisen yhteisön vaatimusten kanssa. Yhteisön ja yksilön intressien ristiriitaisuus näkyy muun muassa tilanteissa, joissa japaninsuomalaiset tekevät kielivalintojaan ja puhuvat lasten kielellisestä kasvatuksesta.

Vastavoimapareista tilanteisuus ja tärkeys kuvaavat sitä, kuinka elämäntilanne ja kielenkäyttötilanne vaikuttavat kielelle annettuihin rooleihin ja merkityksiin. Informanttien mukaan suomen kielen merkitys saattaa vähetä, kun kieltä ei voi käyttää arkielämässä Japanissa (ks. resurssien merkityksen muutoksesta esim. Blommaert 2005). 
Arjen sujuminen ja kielen käyttäminen ovat keskeisiä puheenaiheita. Asian toinen puoli on se, että ulkomailla ollessaan - uudessa tilanteessa - japaninsuomalaiset ovat ymmärtäneet kielen merkityksen uudella tavalla. Suomen tärkeys on tullut esiin, tai lingua francana toimiva englanti on menettänyt merkityksensä. Vaikka kieli on tilanteinen ja mukautuu elämäntilanteisiin, informantit kuvaavat usein kielen tärkeyttä, joka ei ole sidottu Japanin kontekstiin tai mihinkään muuhunkaan kontekstiin. Kielipuheessa siis elää sellainen kielen merkitys, joka on riippumaton muutoksista tai myllerryksistä, ajasta ja paikasta.

Toinen vastavoimapari on muutos ja pysyvyys. Asuinmaa, elämäntilanne ja kielellinen sekä kulttuurinen ympäristö ovat muutoksessa, ja samalla kielikäsitykset ovat liikkeessä. Informantit kuvaavat, kuinka tilanne ja kielen merkitys ovat sidoksissa toisiinsa. Samalla he luovat puhetapoihin aikaulottuvuuden: tietty kielelle annettu merkitys tai identiteettipositio on voimassa nyt tai tällä hetkellä. Ajanilmaukset pitävät sisällään oletuksen siitä, että tilanteet, samoin kuin käsitykset kielestä, voivat muuttua. Lisäksi japaninsuomalaisten diskursseissa näkyy äidinkielen tapauksessa muutos huonompaan. Kieli muuttuu, kun sanoja hukkuu tai englanninkielisiä lainoja tulee kieleen. Sama puhumisen tapa toistuu Suomessa ja myös muiden kielten puhujien keskuudessa. Usein uhkana nähdään vieraat kielet, erityisesti englanti. (Esim. Hiidenmaa 2003: 13-15, 22-23.)

Muutoksen vastavoima taas on pysyvyys, joka on yhteydessä kielen tärkeyteen ja henkilökohtaiseen merkitykseen. Sisin ja syvin kielen merkitys on pysyvää. Toiseksi pysyvyys tarkoittaa toivetta jatkuvuudesta, kielen siirtymisestä jälkipolville. Tässä lasten kielellinen kasvatus tulee keskeiseksi ja perheen kielipoliittisia ratkaisuja pohditaan monipolvisesti aineistoni parikeskusteluissa (perheen kielipolitiikasta esim. Schwartz \& Verschik 2013).

Kolmanneksi pohdin välineellisyyden ja itseilmaisun vastavoimaa. Välineellisyys on näkökulma, jonka informantit käsittääkseni tuovat haastatteluihin ja keskusteluihin ennen kaikkea vallitsevista tilanteistaan käsin. Tällainen näkökulma on täysin ymmärrettävä. On silti muistettava, että kielellä on toisenlainenkin merkitys kuin toimia ainoastaan välittäjänä kommunikaatiossa tai työkaluna. Japaninsuomalaisten diskursseissa tulee esille toinen näkökulma, itseilmaisu. Kielellä ilmaistaan itseä sekä välitetään tunteita ja sävyjä. Syvimmät rakkauden ilmaisut ja vihastumisen tunteet ovat sellaisia, jotka informanttini haluavat ilmaista suomeksi (kielestä ja tunteista esim. Dewaele 2008). Tällainen puhumisen tapa ei ehkä Suomessa asuvalla suomalaisella aktivoidu, mutta tulevaisuudessa se voi olla ajankohtainen. Suomalaisten liikkuvuus lisääntyy kaiken aikaa, ja ympäristömme Suomessa tulee entistä monikielisemmäksi. Missä tilanteissa silloin tarvitaan suomea ja mihin?

Kun kaksi informanttiani keskustelivat kielten merkityksestä tunteiden ilmaisemisessa, he halusivat samalla antaa väitöskirjalleni nimen: mikään ei voi korvata sitä perkelettä. Valitettavasti en voinut nimetä väitöskirjaani informanttien ehdotuksen mukaan, vaikka nimi olisikin ollut osuva. Tuo kyseinen esimerkki ei nimittäin noussut aineistosta esille klustereissa eikä semanttisessa preferenssissä. Tästä päästään siihen, että diskurssianalyysi on aina jäännöksellistä ja lopputulos riippuu ainakin osittain tutkijan valitsemasta aineiston käsittelytavasta eli siitä, kuinka diskurssit saadaan esille 
tekstimassoista. Kun katson työtäni, aihettani ja aineistoani tietystä näkökulmasta, jotain muuta jää näkemättä. Käyttämälläni menetelmällä sain paljon dataa järjesteltyä ja luokiteltua, ja kokosin saamistani tuloksista diskursseja, mutta tällä tavoin jotkin herkulliset esimerkit ja aineistokatkelmat saattoivat jäädä varjoon. Tämä ehkä menetelmän haittapuolenakin nähtävä seikka kuitenkin todistaa sen, että en ole tehnyt työtäni vain poimimalla mielenkiintoisia esimerkkejä (ks. esim. Mason 2002 [1996]: 152) vaan olen noudattanut valitsemaani systemaattista tapaa, jolla lähestyn aineistoani. Se jättää jotain varjoon, mutta samalla pääsen haluamaani lopputulokseen, kun menetelmä paljastaa aineiston toistuvuuksia, itsestäänselvyyksiä ja diskursseja.

Perkele-esimerkki tiivistää työni kielidiskurssit, jotka ovat välillä hyvin ristiriitaisia. Vaikka elämäntilanteet ja kielenkäyttötilanteet ovat siirtolaisuuden konteksteissa hybridejä ja muuttuvia, jotain pysyvää, tärkeää ja muutokselle resistenttiä jää jäljelle. Sisimmät tunteet eivät anna japaninsuomalaisille myönnytyksiä.

\section{Lähteet}

BAKer, PAUl 2006: Using corpora in discourse analysis. London: Bloomsbury.

BAKer, PAul - McEnery, Tony 2015: Introduction. - Paul Baker \& Tony McEnery (toim.), Corpora and discourse studies. Integrating discourse and corpora s. 1-19. Palgrave Advances in Language and Linguistics. Houndmills: Palgrave Macmillan.

Blommaert, Jan 2005: Discourse. A critical introduction. Key Topics in Sociolinguistics. Cambridge: Cambridge University Press.

- 2012: Supervernaculars and their dialects. - Dutch Journal of Applied Linguistics 1 s. 1-14. https:/doi.org/10.1075/dujal.1.1.o3blo.

Blommaert, Jan - RAmpton, Ben 2011: Language and superdiversity. - Diversities 13 (2) S. 1-21.

Boyd, Sally - Palviainen, Ås a 2015: Building walls or bridges? A language ideological debate about bilingual schools in Finland. - Mia Halonen, Pasi Ihalainen \& Taina Saarinen (toim.), Language policies in Finland and Sweden. Interdisciplinary and multi-sited comparisons s. 57-89. Multilingual Matters 157. Bristol: Multilingual Matters.

DeWAELE, JeAn-MARC 2008: The emotional weight of I love you in multilinguals' languages. - Journal of Pragmatics 40 s. 1753-1780. https:/doi.org/10.1016/j.pragma.2008.03.002.

GRÜNThAL, RıHo 2009: Kieliyhteisöjen rapautuminen ja kielellisen identiteetin muutos. 200o-luvun ersämordvalaiset ja vepsäläiset. - Anna Idström \& Sachiko Sosa (toim.), Kielissä kulttuurin ääni s. 265-289. Tietolipas 228. Helsinki: Suomalaisen Kirjallisuuden Seura.

HiidenmaA, Pirjo 2003: Suomen kieli - who cares? Helsinki: Otava.

Jantunen, Jarmo H. 2018: Homot ja heterot Suomi24:ssa. Analyysi digitaalisista diskursseista. - Puhe ja kieli 38 s. 3-22. https://doi.org/10.23997/pk.65488.

Kenny, Dorothy 2001: Lexis and creativity in translation. A corpus-based study. Manchester:

St. Jerome.

Köpke, BARbARA - Schmid, Monika S. 2004: Language attrition. The next page. - Monika S. Schmid, Barbara Köpke, Merel Keijzer \& Lina Weilemar (toim.), First language attrition. Interdisciplinary perspectives on methodological issues s. 2-43. Studies in Bilingualism 28. Amsterdam: John Benjamins. 
Mantila, HARri 2010: Suomalaisen kielenhuollon periaatekeskustelu 1990- ja 2000-luvulla. - Hanna Lappalainen, Marja-Leena Sorjonen \& Maria Vilkuna (toim.), Kielellä on merkitystä. Näkökulmia kielipolitiikkaan s. 179-205. Suomalaisen Kirjallisuuden Seuran Toimituksia 1262. Tiede. Kotimaisten kielten tutkimuskeskuksen julkaisuja 16o. Helsinki: Suomalaisen Kirjallisuuden Seura.

Mason, JeNnifer 2002 [1996]: Qualitative researching. London: Sage.

Mäntynen, Anne - Halonen, Mia - Pietikäinen, Sari - Solin, Anna 2012: Kieliideologioiden teoriaa ja käytäntöä. - Virittäjä 116 s. 325-346.

Pietikäinen, SARI - Mäntynen, Anne 2009: Kurssi kohti diskurssia. Tampere: Vastapaino.

Rintala, Päıvi 1998: Kielikäsitys ja kielenohjailu. - Sananjalka 40 s. 47-65.

Schwartz, Mila - Verschik, Anna 2013: Achieving success in family language policy. Parents, children and educators in interaction. - Mila Schwartz \& Anna Verschik (toim.), Successful in family language policy. Parents, children and educators in interaction s. 1-20. Multilingual Education 7. New York: Springer.

Sсотт, Miкe 2008: WordSmith Tools version 5. Liverpool: Lexical Analysis Software.

Stuв вs, Michael 2001: Words and phrases. Corpus studies of lexical semantics. Malden: Blackwell.

Vertovec, Steven 2007: Super-diversity and its implications. - Ethnic and Racial Studies 30 s. 1024-1054. https://doi.org/10.1080/01419870701599465.

Weскттвӧм, Lотта 2011: Representations of Finnishness in Sweden. Studia Fennica Linguistica 16. Helsinki: Suomalaisen Kirjallisuuden Seura.

Liisa-Maria Lehto: Korpusavusteinen diskurssianalyysi japaninsuomalaisten kielipuheesta. Acta Universitatis Ouluensis. Series B Humaniora 162. Oulu: Oulun yliopisto 2018. Väitöskirja on luettavissa osoitteessa http://jultika.oulu.fi/Record/isbn978-952-62-1909-7.

Kirjoittajan yhteystiedot: etunimi.sukunimi@oulu.fi 